\title{
Reading Strategies Used in Reading Academic Texts by Students of High and Intermediate Reading Proficiency Levels
}

\author{
Johan Setiawan, Nani Indrajani Tjitrakusuma \\ English Department, Faculty of Letters, Petra Christian University, \\ Siwalankerto 121-131, Surabaya 60236, INDONESIA \\ Johansetiawan777@gmail.com
}

\begin{abstract}
In this study, the reading strategies used by students of high and intermediate reading proficiency levels were qualitatively examined. Reading strategies are important factors that affect someone's reading proficiency. In the development of education, reading strategies are continuously carried out to facilitate the learning process and sharpen students' reading skills. The purpose of this study is to discover the reading strategies used by the English Department students with high and intermediate reading proficiency levels in reading academic texts. This study uses reading strategies theory by Grabe (2009) combined with the interview questions by Mokhtari and Reichard (2002) to examine the reading strategies of ten participants consisting of five people with high reading proficiency level and five other people with intermediate reading proficiency level. This study showed that students of high reading proficiency levels tend to use more reading strategies than students with intermediate reading proficiency level. The biggest difference is in the use of text-structure awareness and inferencing strategies. It indicates that the mastery of text structure is directly related to reading effectiveness. Without text structure awareness, other reading strategies such as summarizing, inferencing, and elaborative interrogation will be seriously disrupted.
\end{abstract}

Keywords: Reading Strategies, Academic Text, High Reading Proficiency Level, Intermediate Reading Proficiency Level

\section{INTRODUCTION}

Reading is an important skill for learners of English as a second/foreign language (ESL / EFL). Grabe (2009) says that reading will provide improvement in areas of language learning. According to Pardede, (2019), the learners in the EFL setting study English in an environment where English is not the primary language of the society. Lack of input could be overcome through reading. To acquire good reading skills, a student requires good reading strategies. Rraku, $\mathrm{V}$, (2013), says that the use of reading strategies is directly linked with students' reading skills. Effective reading skills and strategies can affect one's reading ability.

In this study, what is meant by reading academic text is activities carried out for educational purposes both inside and outside the classroom that is carried out by students at Petra Christian University (PCU) while undergoing Reading 4 class. In this study, the researcher specifically discussed reading strategies in the context of reading academic text. Reading 4 is the final stage of reading class in the English Department of PCU curriculum. Students who have passed this class should have a lot of reading experiences and already have their own reading strategies. For this reason, students who have passed the Reading 4 class are chosen as the subjects for this study. Then the reason for choosing high reading proficiency and intermediate reading proficiency is because students who have these proficiencies have and implement enough reading strategies that can be researched so that they can provide enough data to be studied in this study. For this reason, the focus of this study is to discover the reading strategies used by students of high and intermediate reading proficiency levels in reading academic texts. In addition, the researcher 
Setiawan: Reading Strategies Used in Reading Academic Texts by Students of High and Intermediate Reading Proficiency Levels

would like to find out the differences and/or similarities related to the strategies used by those students

To assess the reading strategies used by the participants in reading digital and printed texts, the author uses the theory of eight reading strategies initiated by Grabe (2009, pp. 208-215) and the interview questions by Mokhtari and Reichard (2002). Table 1.1 Reading Strategies by Grabe (2009) Combined with Interview Questions by Mokhtari and Reichard (2002)

\begin{tabular}{|c|c|}
\hline Reading Strategies & Actions to do \\
\hline Summarizing & Taking and understanding the main points of reading text \\
\hline Forming Questions & Generate question-related to the text \\
\hline $\begin{array}{l}\text { Answering } \\
\text { Questions and } \\
\text { Elaborative } \\
\text { Interrogation }\end{array}$ & Answer questions related to reading material \\
\hline $\begin{array}{l}\text { Monitoring } \\
\text { Comprehension }\end{array}$ & $\begin{array}{l}\text { Combine other strategies (Has the purpose of reading, } \\
\text { Recognizing the text's structure, Relating the texts with } \\
\text { prior/background knowledge, recognizing and responding to } \\
\text { problems, clarify the misconception.) }\end{array}$ \\
\hline $\begin{array}{l}\text { Activating prior } \\
\text { knowledge }\end{array}$ & Recall of information \\
\hline $\begin{array}{l}\text { Using text-structure } \\
\text { awareness }\end{array}$ & $\begin{array}{l}\text { Recognizing how the information within a written text is } \\
\text { organized (Level of importance, heading, and subheading, } \\
\text { paragraphing choice, the relation between part to part } \\
\text { information, pattern of organizing text information (main point } \\
\text { and support, definition) }\end{array}$ \\
\hline $\begin{array}{l}\text { Using visual } \\
\text { graphics and } \\
\text { graphic organizers }\end{array}$ & Using graphic organizers and text imagery (imagination) \\
\hline Inferencing & $\begin{array}{l}\text { Making conclusions based on the reading text and previous } \\
\text { knowledge and experience. This process usually involve prior } \\
\text { knowledge activation, vocabulary knowledge, text-structure } \\
\text { awareness }\end{array}$ \\
\hline
\end{tabular}

\section{METHODOLOGY}

To gather the data, the researcher did an interview with ten PCU students. Those ten participants consisted of five people with high reading skill proficiency level and five people with intermediate reading skill proficiency level. The proficiency levels were determined based on the Reading 4 grade obtained by the students. Students who got an A were considered as having high reading proficiency level; while students who got score B were considered as having intermediate reading proficiency level. The data collection was done by doing some particular steps. First, the researcher found 10 English Department people who had passed the Reading 4 class. Second, the researcher contacted the ten students who met the requirements and after that, the researcher told the prospective participants about the interview, asking for permission to use a recording device such as a mobile phone recorder. After that, the researcher and the participants arranged the schedule to do the interview to collect the data. In the interview process, the researcher called the interviewees at the agreed date and time. In one day the researcher could interview one to two people to avoid scheduling conflicts between interviewees. This process continued until all 
interviewees were interviewed. In completing data collection, the researcher spent about two weeks in October 2020.

The researcher employed content analysis theory from Erlingsson and Brysiewicz (2017), that is, by writing the transcript and making data condensation. According to Erlingsson and Brysiewicz (2017), the first step to start the content analysis is by making the transcript. Second, the researcher needs to make condensation of the data to shorten the text while still preserving the core meaning. In the table below, the researcher tried to shorten the data through the condensation process to conclude the point inside the interview dialog.

\section{FINDINGS AND DISCUSSION}

Table 1.2 Reading Strategy Used by Students of High Reading Proficiency Level

\begin{tabular}{|l|l|l|l|l|l|l|l|l|}
\hline \multicolumn{7}{|c|}{ Reading Strategies Used by Students of High Reading Proficiency Level } \\
\hline Students & Sum & Form & Ans & Mon & Act & Text & Vis & Infer \\
\hline Student 1 & V & V & V & V & V & V & V & V \\
\hline Student 2 & V & V & V & V & V & V & V & V \\
\hline Student 3 & V & V & V & V & V & X & X & X \\
\hline Student 4 & V & V & V & V & V & V & V & V \\
\hline Student 5 & V & V & V & V & V & V & V & V \\
\hline $\begin{array}{l}\text { Total } \\
\text { Number } \\
\text { of the } \\
\text { Strategies } \\
\text { Applied }\end{array}$ & 5 & 5 & 5 & 5 & 5 & 4 & 4 & 4 \\
\hline
\end{tabular}

Note: Sum: Summarizing

Form: Forming Questions

Ans: Answering Questions and Elaborative Interrogation

Mon: Monitoring Comprehension

Act: Activating prior knowledge

Text: Using text-structure awareness

Vis: Using visual graphics and graphic organizers

Infer: Inferencing

$\mathrm{V}=$ The student used a particular reading strategy

$\mathrm{X}=$ The student did not use the particular reading strategy

Table 1.3 Reading Strategy Used by Students of Intermediate Reading Proficiency

Level

\begin{tabular}{|l|l|l|l|l|l|l|l|l|}
\hline \multicolumn{6}{|c|}{ Reading Strategies Used by Students of Intermediate Reading Proficiency Level } \\
\hline Students & Sum & Form & Ans & Mon & Act & Text & Vis & Infer \\
\hline Student 6 & X & V & X & V & V & X & X & X \\
\hline Student 7 & V & V & X & V & V & X & X & X \\
\hline Student 8 & V & V & V & V & V & X & V & V \\
\hline Student 9 & V & V & V & V & V & X & V & V \\
\hline Student 10 & V & X & V & V & X & V & V & X \\
\hline
\end{tabular}


Setiawan: Reading Strategies Used in Reading Academic Texts by Students of High and Intermediate Reading Proficiency Levels

\begin{tabular}{|l|l|l|l|l|l|l|l|l|}
\hline $\begin{array}{l}\text { Total } \\
\text { Number of } \\
\text { the Strategies } \\
\text { Applied }\end{array}$ & 4 & 4 & 3 & 5 & 4 & 1 & 3 & 2 \\
\hline
\end{tabular}

Based on the data and analysis results that had been collected, it can be concluded that students of High Reading Proficiency Level often use strategies such as summarizing, forming questions, answering questions and elaborative interrogation, monitoring comprehension and activating prior knowledge. Then followed by text structure awareness, using visual graphics and graphic organizer and Inferencing. Meanwhile, students of Intermediate Proficiency Level used the monitoring comprehension strategy. It was then followed by summarizing, forming questions, activating prior knowledge, using visual graphics and graphic organizers, which was then followed by answering questions and elaborative interrogation, inferencing, and, the most rarely used was text structure awareness.

The following is the data sample showing the use of particular reading strategies. Summarizing can be seen when the respondent said: "By using my own sentences in reading, it makes reading feel simpler and easier to understand. When paraphrasing I focus more on shortening the core of the reading so it's easy to remember". That statement showed that the student used summarizing because summarizing is indicated from the student shortening the reading text to make the text become easier to be understood. Forming questions is seen in this statement: "I do guess the text because I often have expectations for text". That statement showed that the student used forming questions because forming questions is indicated from the student made a guess and questions about the reading text.

Answering questions and elaborative interrogation can be inferred from the following statement: "Yes, sometimes I like to ask other people. What I look for is an implied meaning that is not shown directly in the text". That statement showed that the student used answering questions and elaborative interrogation because answering question and elaborative interrogation is indicated by the student who likes to be involved in a discussion about the reading text. Monitoring comprehension can be seen when the respondent stated that "If there is a part of the text that suddenly concludes something without me knowing its origin, I will usually start reading the text again. If it has happened many times it means that I am no longer focused" That statement showed that the student used monitoring comprehension. Monitoring comprehension is indicated by the student who was aware of his/her focus and concentration while reading.

Activating prior knowledge is seen in this statement: "Background knowledge can connect me to the meaning of the text that I read. The background can also provide important information that you need to know when reading the text". That statement showed that the student used activating prior knowledge which was indicated by the student's using background knowledge to make the text become easier to be understood. Text structure awareness can be seen in this statement: "Yes, usually during an exam I immediately locate the important points in the text to make it easier for me to find certain information in the text". That statement showed that the student used text structure awareness because the student was aware of the text structure such as main point of the text and the supporting detail of the text. Visual graphic and graphic organizer can be inferred when the respondent said: "pictures, charts, and illustrations. It will affect the ease of understanding of the text". That statement showed that the student used visual graphic and graphic organizer because of the use of text visualization such as illustration, chart and diagram to make the text easier to be understood. Inferencing is seen in this statement: "Usually more often replace complex language. I rarely omit parts that don't really matter". That statement showed that the student used inferencing because the student not only shortened the reading text, but also made the text become simpler without reducing the meaning of the text. 


\section{Differences in Reading Strategies between Students of High and Intermediate Reading Proficiency Levels}

There are some clear differences between high reading proficiency and intermediate reading proficiency levels. The most noticeable thing is that students with high reading proficiency levels use more reading strategies than students who have intermediate reading proficiency levels. Except for the monitoring comprehension strategy, both reading proficiency levels used monitoring comprehension with the same score. This means that reading strategies are very influential in reading proficiency. The more reading strategies used in reading, the higher the reading proficiency is.

The difference in reading strategies between students with high reading proficiency and intermediate reading proficiency is in the usage of text-structure awareness. It can be seen that students with high reading proficiency tend to use text-structure awareness, while students with intermediate reading proficiency levels tend not to use it. This is probably because mastery of text structure is directly related to reading effectiveness; without mastery of text structure, readers will be confused about which parts are important and where they are. If that happens, other reading strategies such as summarizing, inferencing, and elaborative interrogation will be seriously disrupted. It will immediately undermine most existing reading strategies. The second difference lies in the inferencing strategy, where students with high reading proficiency level tend to use inferencing strategies while students with intermediate reading proficiency level tend not to use them. Inferencing is the advanced stage of summarizing. Inferencing involves paraphrasing and summarizing. Most students with intermediate reading proficiency level may only be able to summarize at first, while students of high reading proficiency level can apply more reading strategies so that they can perform better inferencing than students with intermediate reading proficiency level.

This difference indicates that students of intermediate reading proficiency level tend not to pay attention to the structure of the text and tend to only read without having a deeper understanding of the meaning of the text. What they do to remember text information is to reduce things that are not important in the text, not to really absorb the meaning while remembering it in their own words. From this, it can also be concluded that the strategies of text-structure awareness and inferencing may play an important role in improving reading proficiency.

The similarity in strategy usage between students of high and intermediate reading proficiency levels is that both levels of proficiency always use monitoring comprehension. Perhaps, this is because they are accustomed to studying in an academic setting, thus, they are accustomed to combining some strategies, responding to reading problems, and clarifying misconceptions. For the complete information, see Table 1.4

Table 1.4 Total Number of Reading Strategies Used by Students of High and Intermediate-Proficiency Levels

\begin{tabular}{|l|l|l|l|l|l|l|l|l|}
\hline & Sum & Form & Ans & Mon & Act & Text & Vis & Infer \\
\hline $\begin{array}{l}\text { High } \\
\text { Reading } \\
\text { Proficie } \\
\text { ncy }\end{array}$ & 5 & 5 & 5 & 5 & 5 & 4 & 4 & 4 \\
\hline $\begin{array}{l}\text { Interme } \\
\text { diate } \\
\begin{array}{l}\text { Reading } \\
\text { Proficie } \\
\text { ncy }\end{array}\end{array}$ & 4 & 4 & 3 & 5 & 4 & 1 & 3 & 2 \\
\hline
\end{tabular}


Setiawan: Reading Strategies Used in Reading Academic Texts by Students of High and Intermediate Reading Proficiency Levels

\section{CONCLUSION}

Based on the findings, the researcher found that the students of high reading proficiency level tend to use more reading strategies than students of intermediate reading proficiency level. The biggest difference is-on the use of using text-structure awareness and inferencing strategies. It indicates that the mastery of text structure is directly related to reading effectiveness. If the students not able to recognize text structure such as the location of points, support in sentences, then automatically the use of other strategies will be seriously disrupted. The bad impact will be seen immediately when students use other strategies such as summarizing, answering questions and elaborative interrogation and inferencing. The essence of the text that should be summarized can be missed, even when discussing students will not be able to properly connect to text content and subject matter. This will have a direct impact on all reading activities carried out by students in class, discussions and exams.

Hopefully, this study can help other students and reading learners to assess themselves and find a better way to improve their reading strategies. Last but not least, for future researchers who are interested in doing research related to reading strategies, the researcher suggests them to do research on other proficiency levels.

\section{REFERENCES}

Erlingsson, C., \& Brysiewicz, P. (2017). A hands-on guide to doing content analysis. African Journal of Emergency Medicine, 7(3), 93-99. doi:10.1016/j.afjem.2017.08.001

Grabe, W. (2009). Reading in a second language: Moving from theory to practice. Cambridge University Press, Cambridge.

Mokhtari, K., \& Reichard, C. A. (2002). Assessing students' metacognitive awareness of reading strategies. Journal of Educational Psychology, 94(2), 249-259. doi:10.1037/0022-0663.94.2.249

Pardede, P. (2019). Print vs digital reading comprehension in EFL: A literature review. JET (Journal of English Teaching), 5(2), 77. doi:10.33541/jet.v5i2.1059

Rraku, V. (2013). The Effect of Reading Strategies on The Improvement of the Reading Skills of Students. Journal of Social and Natural Sciences, 70, 709-714 doi: 10.1016/j.sbspro.2013.01.113. 